\title{
SELF-REGARD IN THE STRUCTURE OF PERSONALITY BEHAVIOURAL MANIFESTATIONS
}

\author{
NADIA LEVUs elpis_lviv@mail.ru \\ Ivan Franko Lviv National University \\ Ukraine
}

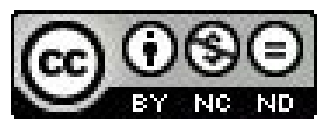

\begin{abstract}
The article focuses on the issue of self-regard connected with behavioural manifestations of personality. By means of comparative, correlation and factorial analysis it is proven that positive self-regard is accompanied by a decreasing level of suicidal risk as well as by creativity growth. Self-acceptance, positive attitude towards oneself ensures a harmonious existence and a high level of personality self-identification. Higher level of self-regard is revealed in younger age categories where it is based on optimistic life prospects and a creative approach to solving life problems. Creativity combined with self-liking becomes a certain ability that helps overcome crisis situations and facilitates removal of personal peculiarities connected with proneness to suicide. Among the creative skills and abilities foregrounded are creative approach, creative imagination and creative intuition.
\end{abstract}

Keywords: self-regard, self-esteem, self-interest, self-understanding, suicidal risk, creativity, creative skills, creative intuition.

\section{PROBLEM DEFINITION}

Analysis of social problems shows that their root causes lie not in the economic, political and social spheres but in the personal sphere and are directly connected with self-consciousness of a person, his/her attitude towards his or her self. Therefore, of importance is understanding of self-regard as an integral personal characteristic that accounts for motivation of behaviour and activity, facilitates integral development of a person, and changes of his/her position in society.

Nowadays self-regard is considered to be the most important element of the whole inner structure of a personality, as a result of interiorization of key social values, that allows one to find one's way in the world of material and spiritual culture of society. Self-acceptance, positive attitude towards oneself ensures harmonious existence and a high level of personality self-identification, emphasizes the active role of a subject in forming positive Self-concept. Thus, positive self-regard is a condition of psychic well-being and psychic health.

\section{ANALYSIS OF RECENT RESEARCHES AND PUBLICATIONS}

The term "self-regard" has emerged relatively recently and has been used by researchers to describe a wide range of phenomena from the inner life of a personality. In psychology the idea of self-regard was for the first time raised by Alexey Leontiev in 1974, before that time the term was not mentioned in academic litera- 
ture. According to the author, the core component of self-regard was the image of Self (Leontiev 1978, p. 237-247).

Nodar Sardzhveladze was the first to introduce the term "self-regard" into the academic vocabulary as a special notion classifying it as a subclass of the social mindset. Considering the phenomenon of self-regard the scholar relates it to the separate sides of self-cognition, self-evaluation, emotional attitude towards oneself, self-control, self-regulation (Sardzhveladze 1983, p. 103-114).

Analysis of researches on psychology published abroad makes it possible to fix the variety of approaches to the problem in question. In particular, Carl R. Rogers subdivides self-regard into self-evaluation (evaluation of self as a bearer of certain features and virtues) and self-acceptance (regarding oneself as unique individuality, who has not only virtues but also drawbacks and faults) (Rogers, Dymond 1954, p.43). Robert B. Burns pinpoints firm conviction in being liked by other people, confidence in the ability to do this or that activity and feeling one's own significance (Burns 1982, p.39). L. Edward Wells, Gregory A. Marwell speak about the feeling of personal competence, commitment and self-liking (Wells, Marwell 1976, p.101).

Considering self-regard through the prism of self-consciousness origin scholars stress that self-regard of a personality is included as a certain substructure unit into the general system of person's relationships (Myasishchev 1995, p.118-162). Attitude of a personality towards self determines his/her attitude towards all the other things, dictates his/her actions, and performs a regulatory function.

In his works Igor Con stresses the cognitive constituent as a key to the process of self-regard formation. The author states that "adults single out in themselves more features than adolescents, adolescents - more than teenagers, teenagers more than children; generalization of those features understood grows as well, moreover, it is closely connected with intellect development" (Con 1984, p. 266267). The scholar interprets the component of self-regard from the viewpoint of differentiation and cognitive complexity of the "Self-image" which subsequently grows from young age to adult age.

At the same time in the works by David H. Demo, Stanley Coopersmith, Morris Rosenberg self-regard is considered as a certain personal feature that undergoes little change from situation to situation and even from one age period to the other. On the basis of self-regard stability lie two key inner motives: the motive for selfesteem and the need for stability of the "Self" image.

The results of Vladimir Stolin's research reveal that one's protection of oneself from antipathy is the most important aspect of self-regard protection. As the scholar states, the basis of self-regard is the need for self-actualization, when personal Self becomes a defining condition for self-realization (Stolin 1983, p. 252).

Self-regard is also considered as a specific type of emotional experience where the personal attitude of a personality towards what he or she finds out, understands, or "discovers" about him or herself is reflected.

The theoretical basis for understanding self-regard as a self-consciousness constituent was laid down by Irine Chesnokova who introduced into academic use a notion of "emotional and axiological self-regard" as a specific type of emotional experience where personal attitude of a personality towards what he or she cog- 
nizes, understands, "discovers" about his or her self is reflected (Chesnokova 1977, p. 54).

Formation of self-regard as an affective component of self-consciousness is done on two levels of self-cognition. At the first level emotional and axiological self-regard appears as a result of correlating oneself with other people. Here there is no integral, real understanding of oneself connected with realizing one's essence. The key form of self-cognition in the comparison "Self-Others" is selfperception and self-observation. At the second, more mature level of self-cognition self-regard formation is done within the comparison "Self-Self" by means of internal dialogue. The key forms of such self-cognition are self-analysis and selfawareness (Kolyshko 204, p. 68-69).

Most promising in modern psychology is the study of self-regard as a direct representation in consciousness of a personal sense "Self". Here self-regard is not based on the evaluation of social desirebility of one's features and is not a direct consequence of knowledge about oneself. Here the basis of self-regard is the evaluation by a personality of his/her "Self", personal features through the motives that express his/her need for self-realization. In this situation the subject treats his/her "Self" depending on whether it is accepted as a negative, positive or in conflict (contradictory) condition for achieving personality motives. Thus, attitude of a person towards oneself can be positive („,Self" is a condition that facilitates self-realization), negative („,Self" is a condition that inhibits self-realization) or conflict (,Self" is a condition that at the same time facilitates and inhibits self-realization) (Panteleev 1991, p. 72).

John A. Hattie writes that feelings of personal dignity influence blocking and accuracy of the measure of our perception. According to the researcher, a person dose not perceive oneself and other people exclusively on the basis of rational abilities. Self-regard of a person influences the whole range of those behavioural aspects that deserve attention and respect. A person with high feeling of own dignity very often considers aspects of his/her own life as important, believes in their realization, perception of oneself, one's own actions in a more integral way and is more aware of it (Hattie 1992, p. 49).

C. R. Rogers stresses that a basic condition of manifestation of personality's flexibility when evaluating oneself as a subject of interpersonal relations is its unconditional accepting oneself as a personality. It is the very unconditional self-acceptance that is the basis for fully fledged functioning of a personality, its openness to inner emotional experience. It ensures the possibility of a person to perceive oneself and other people without distortions and contradictions, interaction with others without protections, while conditional self-acceptance causes instability of self-regard, its dependence on the evaluations of other people (Rogers, Dymond 1954, p. 39).

The conducted analysis allows us to state that there are various approaches to attitude of a person towards oneself: understanding self-regard as affective component of self-consciousness (self-regard in the structure of self-consciousness and self-perception), as a personality feature (self-regard in the personality structure), as a self-regulation component (self-regard in the system of self-regulation), as a factor that influences perception of other people (self-regard in the structure of interpersonal ties). 
In psychology there are numerous researches determining close relations between attitude of a personality towards oneself as to the subject of life attitudes and his/her behaviour (R.B. Burns, S. Coopersmith, J.A. Hattie, S. Panteleev, N. Sardzhveladze). They indicate that high self-esteem of a personality is a condition of its maximum activity, productivity of actions, realization of creative potential, influences freedom of feelings manifestations, level of self-openness in communication (Rogers, Dymond 1954, p. 39). Positive stable self-regard lies in the basis of person's belief in one's own abilities, it is connected with one's readiness to take a risk, stipulates optimism concerning expectations of a successful outcome of one's actions (Kolyshko 204, p. 68-69).

Negative, conflict attitude of a personality towards oneself leads to offences against the law, drug-addiction, alcoholism, aggressive and suicidal behaviour, it is connected with non-adaptive, asocial forms of behaviour and is one of the reasons for deviation (I. Con, A. Nalchadzhian, H.B. Kaplan) and also positively correlates with depression (Coopersmith 1967, p. 331).

\section{AIM OF THE RESEARCH}

Thus, the above-mentioned approaches allow us to outline the problem of our research where an attempt will be made to reveal peculiarities of self-regard as they impact onto two totally opposite behavioural aspects - suicidal and creative behaviour, to be exact, personal peculiarities that facilitate formation of the former or latter.

\section{METHODOLOGY OF THE RESEARCH}

The following psychological methods were used in the empirical research of self-regard peculiarities: Test-questionnaire of self-regard elaborated by V. Stolin, Questionnaire of suicidal risk by Tatyana Rozuvaeva, Creativity test by Natalya Vyshniakova. To process the results obtained the following methods of mathematical statistics were used: cluster, comparative, correlation and factorial analysis.

Below is the short description of the aim and content of the methodology applied.

The test-questionnaire of self-regard elaborated by V. Stolin is aimed at researching the complex of self-regard factors. The test allows to reveal three levels of self-regard that differ in generalization level: 1) global self-regard; 2) self-regard differentiated in terms of self-esteem, self-liking, self-interest and expectations of attitude of others towards oneself; 3 ) level of specific actions (readiness for such actions) in attitude towards one's "Self".

The questionnaire of suicidal risk is used to reveal the level of suicidal intentions formation and to build a profile according to nine subscales: demonstrativity, affectivity, uniqueness, inability, social pessimism, break of cultural barriers, maximalism, time perspective and suicidal factor.

The creativity test by N. Vyshniakova allows us to reveal the level of creative inclinations of a personality according to the following scales: creative thinking, curiosity, originality, imagination, intuition, emotionality and empathy, sense of humour, creative attitude towards one's profession. 


\section{THE GROUP OF RESEARCH PARTICIPANTS}

Participants of the research make up three groups that differ in age and type of occupations. The older age group includes people that have a second higher education in "Psychology". They are from 25 to 45 years old. The majority of the group includes people who either were unable to realize themselves in their first major or try to go up the career ladder getting one more educational qualification and a small number of people who have higher education for self-knowledge and self-development. The number of people in the first group is 54 persons.

The other groups are younger in terms of age and are of approximately the same age - 18-20. The first group includes students that receive psychological education and are full-time students. The group numbers 52 persons. The second group consists of students majoring in Applied and Decorative Arts. The group numbers 40 students. Thus, the general number of those researched is 146 persons.

So, there are three groups under research and there is an assumption that the level and quality of self-regard will be different. Self-regard in the older group will undergo transformation due to professional requalification. In the first young group self-regard is developing owing to formation of self-consciousness and self-cognition which is facilitated by the academic disciplines in various fields of psychology. In the second young group self-regard is connected with realization of one's creative potential.

\section{ANALYSIS AND INTERPRETATION OF THE RESULTS OBTAINED}

To reveal the differences among the groups under study comparative analysis was applied. To verify the hypothesis that certain indicators of the tests influence the difference among the groups one-factor dispersion analysis was applied the results of which demonstrated significance of the following indicators: expectation of positive attitude ( $\mathrm{F}=3.15$ with $\mathrm{p}<0.05)$, self-interest $(\mathrm{F}=3.82)$, self-understanding $(\mathrm{F}=4.60)$, which are the scales of self-regard, as well as demonstrativity $(\mathrm{F}=6.52)$, uniqueness $(\mathrm{F}=11.04)$, social pessimism $(\mathrm{F}=3.36)$, break of time perspective $(\mathrm{F}=4.62)$ as subscale of suicidal risk, and originality $(\mathrm{F}=5.80)$ and sense of humour $(\mathrm{F}=5.97)$ that relate to creativity. As one can see, certain indicators from all those used in the research influence the difference among the groups.

Further verification of statistical differences among the groups was done by means of Scheffe Test.

Among self-regard indicators significantly different is the integral indicator of self-interest $(p=0.239$ with $p<0.05)$ and its subscale $(p=0.0425)$. Both in the first and in the second case higher level of self-interest was observed in the third group students studying at the speciality "Psychology" (Fig. 1). Thus, they have higher interest in their own thoughts and feelings, they are ready to communicate with oneself on the equal level, are confident in being interesting for other people. It is evident that regular classes in psychology promote this because the ability to discover oneself is based on the idea of being interested in oneself as unique individuality. 
Fig. 1. Comparison of self-regard indicators in three groups under research

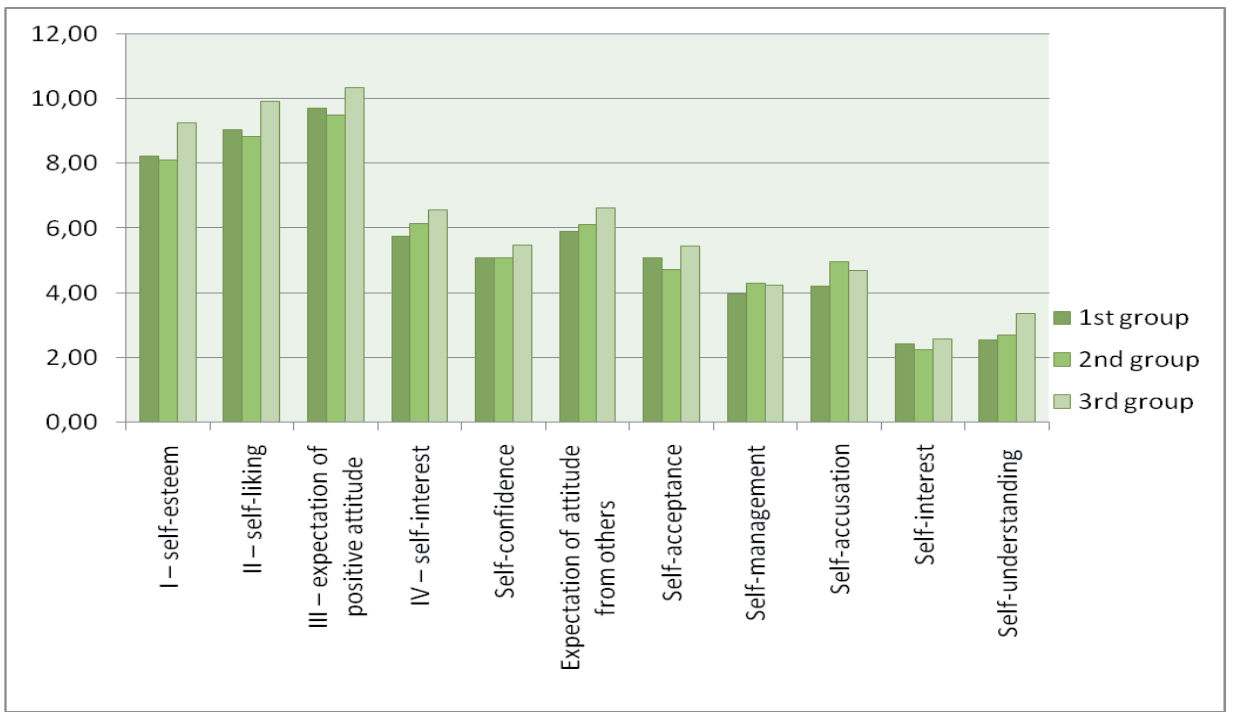

Source: Author.

Fig. 2. Comparison of suicidal risk indicators in three groups under research

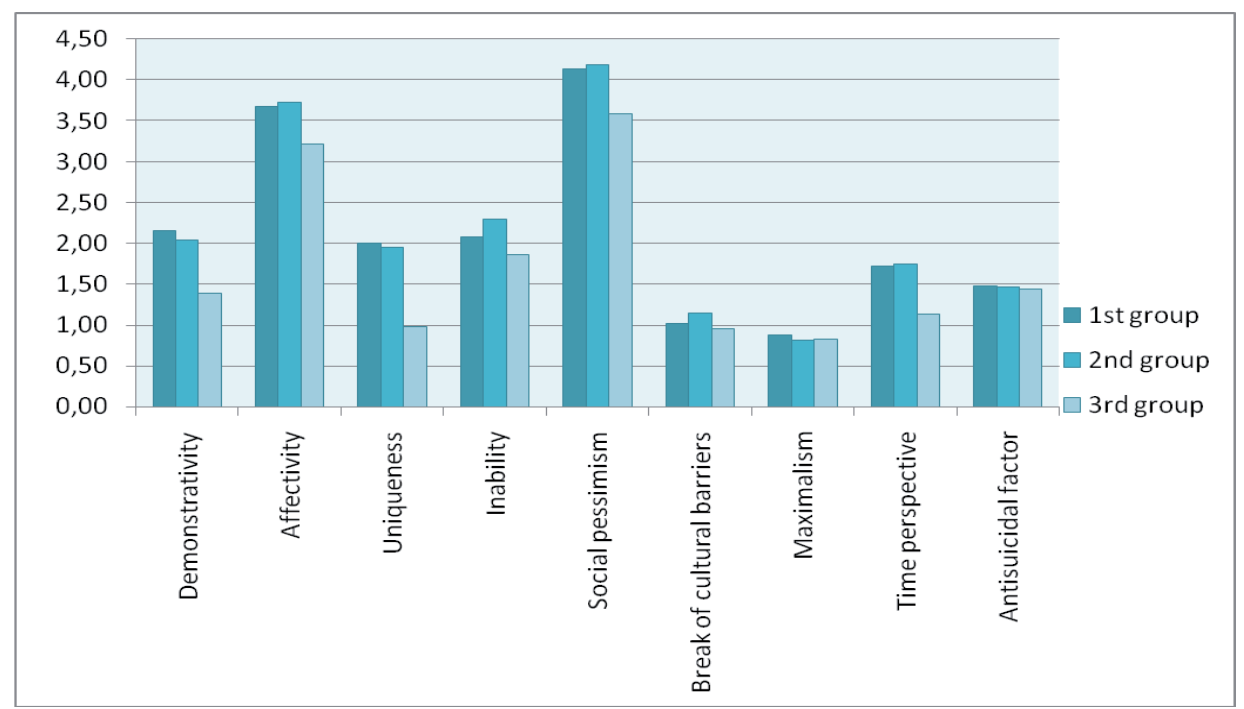

Source: Author

The same concerns self-understanding the level of which is significantly higher in this group of students as compared to those getting second higher education $(p=0.0244)$. To some extent here there is a contradiction to the theory of I.S. Con about growth with age of the ability to differentiate one's personal features. How- 
ever, it can be connected with the fact that with evaluation of the level of this quality the younger people were less objective considering their self-understanding being high. It is necessary to note that at the same time there are no statistically significant differences between the first and the second groups, i.e. between senior students-psychologists and junior students-decorators $(p=0,8657)$.

If compared with these two groups, the third group revealed quite lower subscales of suicidal risk such as demonstrativity $(\mathrm{p}=0.0068$ and $\mathrm{p}=0.0140)$ and uniqueness ( $p=0.0005$ and $p=0.0003$ ) (Fig. 2). They less frequently try to attract other people's attention to their misfortunes, get sympathy and understanding, they do not accept life situations as unique and different from others that reduces the level of suicidal risk.

Break of time perspective as inability to constructively plan one's future happens more frequently with students-decorators as compared to the students-psychologists of the early adulthood ( $p=0.0263)$. It can be the consequence of deep penetration into the current situation, global fear of future failures and defeats. These fears can be removed owing to the increase in the level of self-understanding and, consequently, self-regard.

Let us consider the differences among the groups in terms of creative indicators.

Originality proved to be lower in the second group that includes students majoring in Applied and Decorative Arts as compared with the first group of those getting second higher education $(\mathrm{p}=0.006)$. At first sight, these findings are quite unexpected but they may be explained by lower experience and education of younger students. It is also supported by the fact that between two younger groups there were no differences (Fig. 3).

Fig. 3. Comparison of creativity indicators in three groups under research

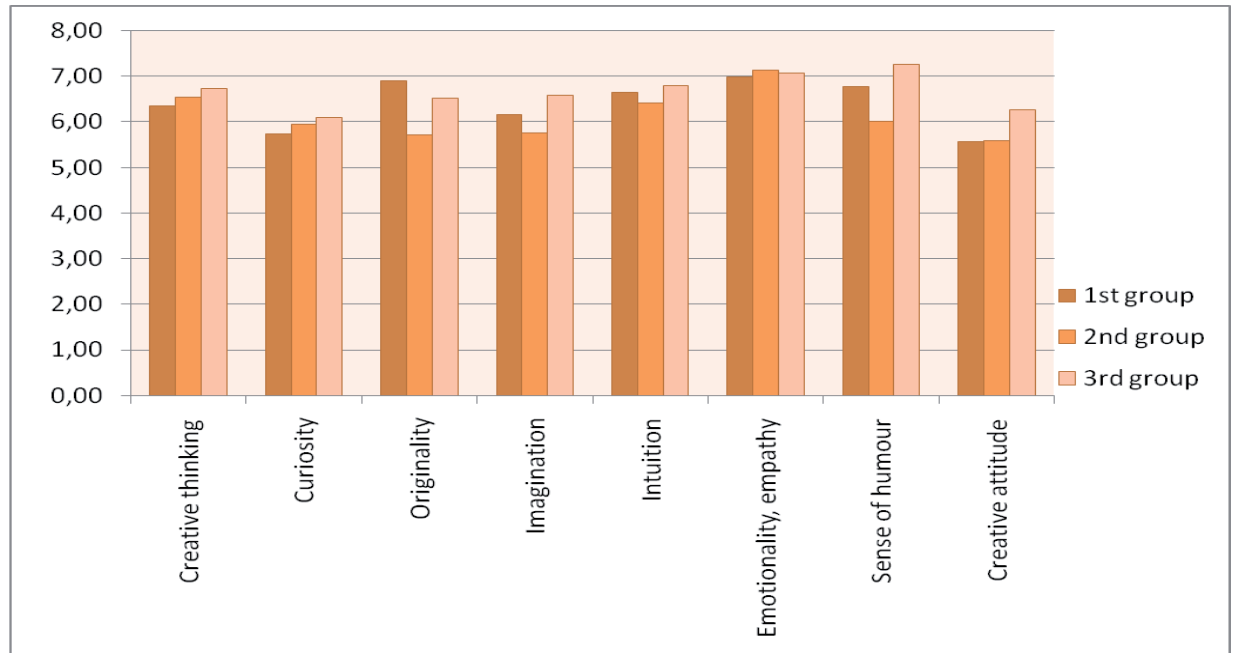

Source: Author.

Students-psychologists and students-decorators differ in sense of humour. The former show higher results with this indicator $(p=0.0035)$. In this case sense of 
humour may maintain general positive emotional background which is the basis for positive self-regard.

In general, students-psychologists participating in the research showed higher level of self-regard that is accompanied by the low level of suicidal risk and high level of creativity.

If to consider correlation analysis of the combined results of all the three groups, it is possible to trace regularities of self-regard interrelations with the indicators of the other tests. With $\mathrm{p}<0.05$ the results showed significant correlations with four indicators of Creativity test, namely originality $(\mathrm{r}=0.226)$, intuition $(\mathrm{r}=0.298)$, sense of humour $(\mathrm{r}=0.229)$ and creative attitude to one's job $(\mathrm{r}=0.358)$. It supports our hypothesis that self-regard is directly related to creativity as creative self-expression raises personality value in one's own eyes. At the same time positive self-regard helps achieve success in creative activity and demonstrate originality of thoughts and ideas.

The integral indicator of self-regard and its subscale reversely correlates with eight indicators of suicidal risk questionnaire, among which - demonstrativity $(\mathrm{r}=-0.363)$, affectivity $(\mathrm{r}=-0.455)$, uniqueness $(\mathrm{r}=-0.405)$, inability $(\mathrm{r}=-0.456)$, social pessimism $(\mathrm{r}=-0.252)$, time perspective $(\mathrm{r}=-0.519)$, antisuicidal factor $(\mathrm{r}=-0.246)$. Thus, the majority of emotional and suicidal manifestations that can lead to suicidal behaviour do not go along with positive self-regard, self-esteem, self-interest and expectation of positive attitude towards oneself from others. On the basis of the above-mentioned it is possible to come to the conclusion that growth of inner feeling "for" oneself, development of the skill to understand oneself, trust oneself will facilitate the correction of suicidal intentions.

Fig. 4. Clusters singled out according to integral scales of self-regard

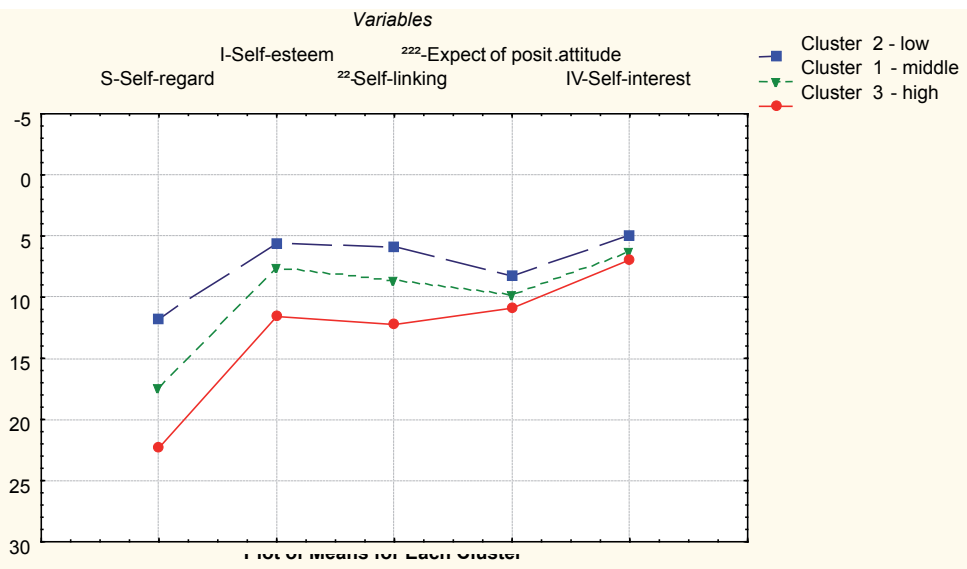

Source: Author.

To fully determine the essence of self-regard we have conducted cluster analysis which allowed us to single out three groups with different level and different aspects of self-regard. 
The basis for the division were integral scales of self-regard where the researched with high results made up the third cluster, those with average results - the first cluster, and the third cluster included those with low results in Testquestionnaire of self-regard (Fig. 3).

The group with high results in terms of self-regard (third cluster) included $49 \%$ students-psychologists, 30\% students getting second higher education and $21 \%$ students-decorators. The group with low results in terms of self-regard included $39 \%$ students undergoing requalification, 33\% students majoring in "Applied and Decorative Arts" and 28\% of the students majoring in "Psychology".

Students-decorators were divided in the groups in the following way: the group with higher results included $30 \%$, with middle $-44 \%$, with low $-26 \%$. The division was different with students-psychologists: $50 \%$ belonged to cluster which included people with high level of self-regard, $31 \%$ - to cluster with middle level of self-regard, and 19\% - to cluster with low level. The division of the students getting second higher education and who are older in terms of age was almost the same as to that of students-decorators: $28 \%$ were in the cluster with high results, $42 \%$ - with middle and $30 \%$ - with low (Tab. 1).

Thus, the participants of the research at the age of early adulthood who study to be psychologists are more prone to have positive and high self-regard which is not the case with persons belonging to the other groups.

Tab. 1. Division of research participants into clusters

\begin{tabular}{|c|c|c|c|}
\hline & $\begin{array}{c}\text { Students-decora- } \\
\text { tors }\end{array}$ & $\begin{array}{c}\text { Students-psychol- } \\
\text { ogists }\end{array}$ & $\begin{array}{c}\text { Students getting } \\
\text { second higher } \\
\text { education }\end{array}$ \\
\hline Cluster 3 - high & $30 \%$ & $50 \%$ & $28 \%$ \\
\hline Cluster 1 - middle & $44 \%$ & $31 \%$ & $42 \%$ \\
\hline Cluster 2 - low & $26 \%$ & $19 \%$ & $30 \%$ \\
\hline
\end{tabular}

Source: Author.

In order to more accurately determine the differences between the groups one-factor dispersion analysis was used as well as comparative analysis based on Scheffe test and Student's t-criterion.

One-factor dispersion analysis has shown that integral scales and their subscales on self-regard significantly influence the differences among the groups which were determined on the basis of cluster analysis. The same is true about the indicators of suicidal risk six of which appeared to be significant for the division. Among creative indicators the most significant influence onto the division of the groups have creative thinking $(\mathrm{p}=0.0414$ with $\mathrm{p}<0.05)$, creative attitude towards one's activity $(\mathrm{p}=0.0137)$ and creative intuition $(0.0002)$. These results prove that participants of the research with different level of self-regard also differ in certain manifestations that concern suicidal or creative behaviour.

Further comparison of the results according toScheffe test confirmed that the hypothesis was correct. The group with high level of self-regard has lower results on scales of suicidal risk and higher results on creativity indicators. Generally, in their behaviour 
they show less demonstrativity, affectivity, inability, that can be accompanied by the feeling of situation uniqueness and break of time perspective. On the contrary, groups with middle and low level of self-regard more frequently demonstrate intentions to attract attention of other people, trying to get their sympathy and understanding. Such behaviour is based on domination of emotions in situation evaluation, reduction of possibility to constructively plan one's future, fear of potential failures (Fig. 5).

Fig. 5. Indicators of suicidal risk in groups with different level of self-regard

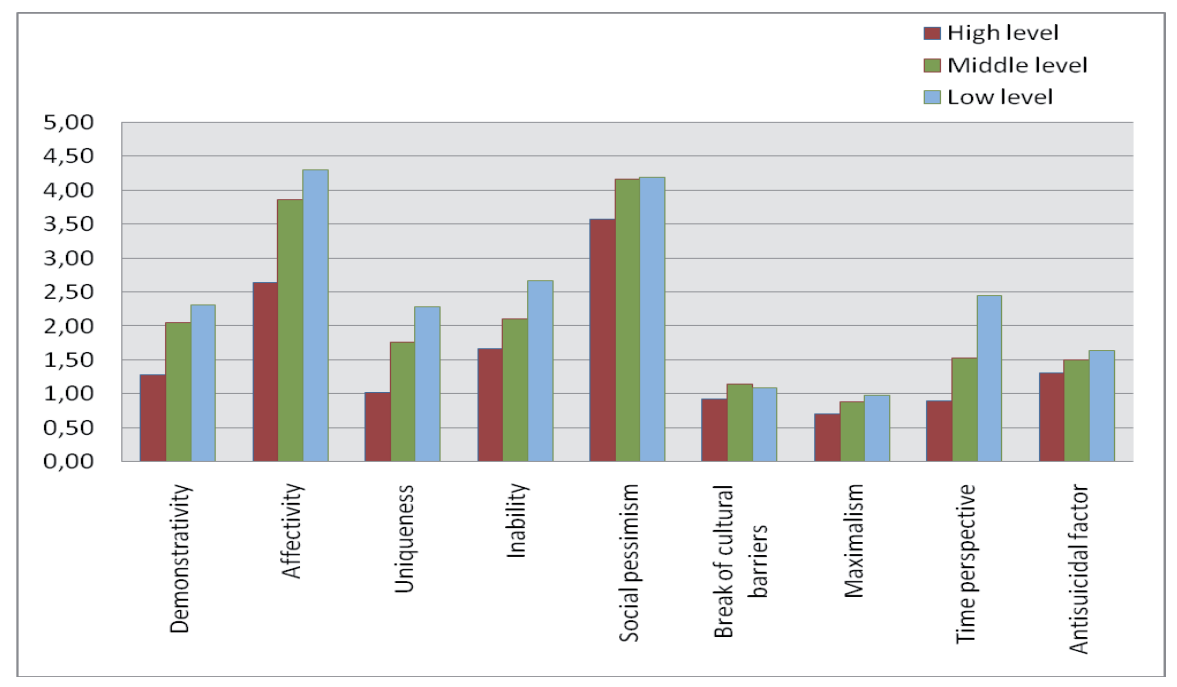

Source: Author.

As far as creative manifestations are concerned, those under research with high self-regard and self-esteem have demonstrated higher level of creative thinking and creative attitude to one's job unlike those under research with middle self-regard. The group with high level of positive attitude towards oneself also significantly differs from the group with its low level in the indicator of creative intuition that helps creatively on the intuitive level solve difficult life problems and avoid failures (Fig. 6).

Correlation analysis was conducted for every cluster but the biggest number of important correlations between self-regard and other indicators was revealed particularly for the group with high level of self-regard. Therefore, we shall concentrate on significant correlations that were singled out in the results of this group.

Integral indicator of self-regard reversely correlates with three scales of the Questionnaire of suicidal risk: affectivity $(\mathrm{r}=-0.314$ with $\mathrm{p}<0.05)$, inability $(\mathrm{r}=-0.291)$ and social pessimism $(\mathrm{r}=-0.417)$. Thus, growth of positive self-regard is accompanied by the reduction of readiness to react to psycho-traumatic situation too emotionally, removal of the feeling of incompetence, inability, re-orientates into positive way acceptance of the world as an enemy (Fig. 7).

The Indicator of self-esteem is inversely interconnected with affectivity $(\mathrm{r}=-0.352)$, social pessimism $(\mathrm{r}=-0.445)$ and maximalism $(\mathrm{r}=-0.306)$ as scales of suicidal risk. Confidence in one's own abilities, skills, feeling the possibility to control 
one's life, understanding oneself facilitates removal of too emotional reaction to negative situation, affective fixations on failures that in extreme cases can lead to "death aesthetization".

Fig. 6. Indicators of creativity in the groups with different level of self-regard

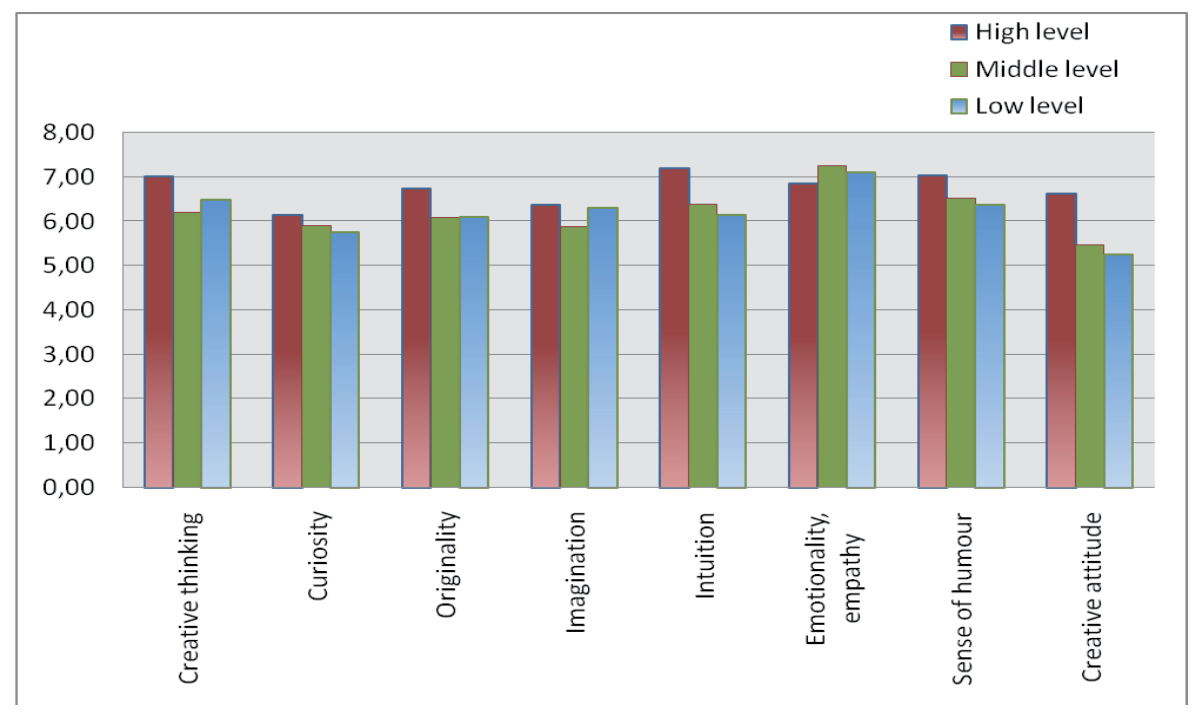

Source: Author.

Fig. 7. Correlation of self-regard with suicidal subscales

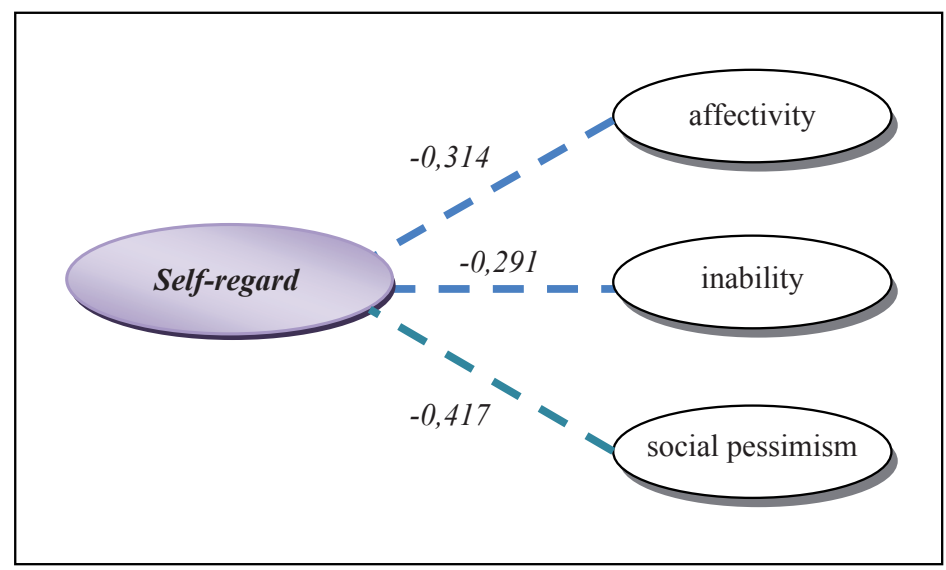

Source: Author.

Let us have a look at the analysis of correlation results of the Creativity test. Here self-regard is significantly connected with sense of humour as a possibility to accept negative situations in an emotionally light way ( $\mathrm{r}=0.395$ with $\mathrm{p}<0.05)$.

The scale of self-liking as an approval of oneself in general and in some important details, trust of oneself and positive self-evaluation directly correlates with 
creative imagination $(\mathrm{r}=0.337)$, intuition $(\mathrm{r}=0.363)$, sense of humour $(\mathrm{r}=0.272)$ and reversely - with emotionality and empathy ( $\mathrm{r}=-0.287)$. Liking one's "Self" facilitates manifestations of creative approach, ability to solve the current tasks in an original and flexible way (Fig. 8).

As we see, correlation analysis confirmed our hypothesis that positive selfregard is accompanied by self-esteem to one's own personality, attitude to it as the highest value that reduces risk of suicidal intentions. At the same time, high level of self-regard is interconnected with creative manifestations, namely, creative imagination, intuition and ability to approach life problems with humour.

Fig. 8. Correlation of self-liking with creativity indicators

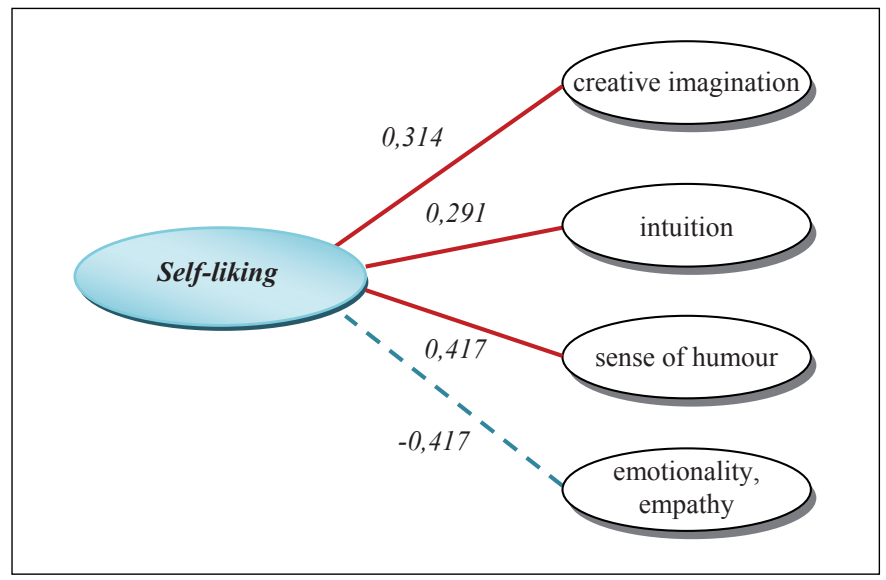

Source: Author.

Let us consider factorial analysis of the results of groups with different level of self-regard.

In the group with high level of self-regard eight factors were singled out which describe $66.62 \%$ of general dispersion. Significant were those factor loads the value of which was over 0.700 . The first factor, which share of general dispersion is $14.51 \%$, encompasses integral indicator of self-liking (0.887) and indicator of self-accusations (-0.829). Thus, of utmost importance for the participants of the research with high level of self-regard were trust and friendly attitude towards oneself which is based on positive self-regard.

The second factor with $12.32 \%$ of the general dispersion included creative thinking (0.772) and intuition (0.707). These are the indicators that concern creativity as an ability to demonstrate non-standard, original and flexible approach to solving problems.

The third factor of the group with high level of self-regard, where the part of the general dispersion is $8.79 \%$, includes integral indicator of interest $(0.885)$ and its subscale (0.867). It shows that those under study are quite close to themselves, in particular, they show interest in their own thoughts and feelings, are ready to communicate with oneself "on equal terms", are confident in being interesting for others. 
Factorial structure of the group with the middle level of self-regard turned out to be different. Similarly to the first group, eight factors that describe $67.34 \%$ of the general dispersion were singled out. The first factor ( $16.31 \%$ of the general dispersion) combined four indicators of suicidal risk: demonstrativity (0.807), uniqueness (0.809), inability $(0.727)$, broken time perspective $(0.732)$. Foregrounded here are the attempts to attract the attention of those who are around one's problems, feelings of uniqueness of these problems and personal incompetence to solve them that leads to inability to constructively plan one's future.

The second factor of the group with middle self-regard $(12.17 \%$ of the general dispersion) is similar in terms of the indicators it consists of to the second factor of the group with high level of attitude towards oneself. As it was in the previous groups, it includes creative indicators, namely, originality $(0.837)$ and creative intuition (0.728). Thus, these indicators are rather significant and tell about the intentions to find nonstandard approaches to solving problematic situations and tasks.

Similarly to the first group, the third factor combined two indicators of self-interest (0.833 and 0.754$)$ that reflect interest in oneself, one's own thoughts and feelings.

Unlike two previous groups, factorial structure of the group with low level of attitude towards oneself turned out to be absolutely different. Eight significant factors were determined that describe $77.99 \%$ of the general dispersion. The first factor, with $18.20 \%$ of the general dispersion, included three suicidal scales: demonstrativity (-0.898), affectivity (-0.756), uniqueness (-0.901). Of interest is the fact that these indicators have a reverse sign that testifies about characteristics directly opposite to these scales: closeness, emotional control, perceiving difficult situations as common ones.

The second (11.29\% of the general dispersion) and third $(9.79 \%$ of the general dispersion) factor relate to six scales of self-regard. The first one combined integral scales of self-regard (0.797) and self-liking (0.826), as well as scales of selfconfidence $(0.756)$ and self-acceptance $(0.854)$, while the second factor combined integral scale „Expectation of positive attitude from others" (0.723) and its subscale (0.854). As we see, for this group of those under research self-regard in all its aspects and manifestations prove to be rather important.

As far as creative indicators are concerned, they belong to factors with less share of general dispersion and have reverse sign. So, to the fourth factor belong creative intuition (-0.755) and creative attitude (-0.565), and to the seventh - curiosity (-0.734). Thus, unlike the groups with high and middle level of self-regard, the group with the low level showed indicators of creativity as less significant.

\section{CONCLUSIONS}

Thus, in psychology self-regard is considered as a complicated cognitive and affective formation whose maturity is determined by the quality of interrelation and degree of agreement of its constituents. Its structure consists of two components: rational and emotional and axiological attitude to oneself, i.e. rueful feelings and evaluation of personal value.

Self-regard plays an important role in the behavioural and emotional manifestations of a person. Negative self-regard often leads to suicidal risk resulting 
from decrease of self-esteem, self-liking and self-interest. Positive self-regard is accompanied by growth of creativity level. Creativity becomes a certain skill that helps overcome stressful situations and facilitates removal of personal peculiarities connected with proneness to suicide. Among the creative skills and abilities foregrounded are creative approach, curiosity and creative intuition.

Summing up, one can state that self-regard is an important psychological category that is closely connected with cognitive and moral spheres of a personality and occupies a central place in the psychological regulation of activity. By means of a mature attitude to oneself a person can really influence his/her own life and the lives of other people, organize his/her life in a sensible way, forecast life events and their results.

\section{BIBLIOGRAPHY}

Burns R.B. (1982), Self-concept development and education, Holt, Rinehart \& Winston, London.

Chesnokova I. (1977), Проблема сознания $b$ психологии (The problem of consciousness in psychology), Наука, Москва.

Con I. (1984), В поисках себя. Личность и ее самосознание (In search of self. Personality and its identity), Издательство политической литературы, Москва.

Coopersmith S. (1967), Ten antecedents of self-esteem, Freeman, N.Y.

Hattie J. (1992), Self-Concept, Hillsdale, New Jersey Howe and London.

Kaplan H.B. (1975), Self-regards and Deviant Behavior, Pacific Palisades, Calif.

Kolyshko А. (2004), Психология самоотношения (Psychology of self-relation), ГрГУ, Гродно.

Leontiev А. (1978), Деятельность. Сознание. Личность (Activity. Consciousness. Personality), Политиздат, Москва.

Nalchadzhian A.A. (2000), Я-концепция (Self-concept), [in: Raigorodsky D. (eds.), Психология самосознания: Хрестоматия (Psychology of consciousness: Chrestomathy), Издательский дом „БАХРАМ-М”, Самара.

Panteleev S.R. (1991), Самоотношение как эмоционально-оценочная система (Self-regard as emotional and evaluation system), Издательство Московского университета, Москва.

Rogers C.R., Dymond R.F. (1954), Psychotherapy and personality change, University of Chicago Press, Chicago.

Raigorodsky D. (eds.) (2000), Психология самосознания: Хрестоматия (Psychology of consciousness: Chrestomathy), Издательский дом „БАХРАМ-М”, Самара.

Rubinstein S.L. (1957), Бытие и сознание. О месте психического в общей взаимосвязи явлений материального мира (Being and consciousness. The place in the overall relationship of mental phenomena of the material world), АН СССР, Москва, 1957.

Sardzhveladze N.I. (1983), Личность и ее взаимодействие с соииальной средой (Personality and its interaction with the social environment), Мецниереба, Тбилиси.

Spirkin A.G. (1972), Сознание и самосознание (Consciousness and self-consciousness, Политиздат, Москва.

Stolin V.V. (1983), Самосознание личности (Self-consciousness of of personality), Издательство Московского университета, Москва.

Wells L.E., Marwell G. (1976), Self-Esteem. - Its conceptualization and measurement, Sage Publication, Beverly Hills, SA. 